\title{
Pewarisan Tari Topeng Gaya Dermayon: Studi Kasus Gaya Rasinah
}

\author{
Nur Rochmat ${ }^{1}$ \\ Jurusan Tari, Sekolah Tinggi Seni Indonesia (STSI) Bandung
}

\begin{abstract}
ABSTRAK
Tulisan ini membahas guru panggung, sebuah proses pewarisan Tari Topeng Gaya Dermayon dari seorang empu kepada muridnya. Proses ini dilakukan oleh Rasinah, empu tari topeng kepada cucunya, bukan kepada anaknya. Penelitian ini menggunakan metode sejarah, yang terdiri dari empat tahap: heuristik, kritik, interpretasi, dan historiografi. Untuk menganalisis ini digunakan teori sistem pewarisan dan teori motivasi. Hasil penelitian menunjukkan bahwa salah satu alasan Rasinah lebih memilih mewariskan kepada cucunya karena cucunya memiliki motivasi yang tinggi untuk menjadi seorang Dalang Topeng.
\end{abstract}

Kata kunci: Pewarisan, Tari Topeng, Gaya Dermayon

\begin{abstract}
Pewarisan Tari Topeng Gaya Dermayon: Studi Kasus Gaya Rasinah. This article discusses the inheritance process of Dermayon Style Mask Dance. In 2008 Rasinah bequeathed Dermayon Style Mask Dance formally to her granddaughter, Aerli. This article analyzes the reasons of the inheritance of Dermayon Style Mask Dance from Rasinah to her granddaughter, not to her own daughter, Wacih. The theories which are applied to analyze the subject are the theory of "Transmission (Inheritance) System" stated by Cavalli-Sforza and Feldman, and the theory of "Motivation" by Abraham H. Maslow, Robert Session Woodworth and Clark Hull. The result of the research shows that one of the reasons that the daughter did not inherit Dermayon Style Mask Dance is due to her lack motivation on being a Mask Dancer (Dalang Topeng).
\end{abstract}

Keywords: inheritance, Dermayon Style Mask Dance

\section{Pendahuluan}

Pada umumnya kemampuan menari topeng yang dimiliki oleh para Dalang Topeng (penari utama) merupakan bakat keturunan yang diwariskan dari nenek moyang mereka. Dalang Topeng dalam pengertian masyarakat Cirebon ialah penari utama dalam sebuah rombongan Tari Topeng, misalnya rombongan Topeng Rasinah dari Pekandangan, Dalang Topengnya ialah Rasinah. Beberapa Dalang Topeng yang sudah terkenal seperti Dasih dan Suji dari Palimanan, Dewi dan Sawitri dari Losari, Sujana dari Slangit, serta Rasinah dari Indramayu berkeyakinan bahwa kemampuan mereka sebagai Dalang Topeng merupakan turunan dari nenek moyang mereka (Rasidin, 2004: 31).

Di kalangan seniman Cirebon ada dua istilah yang biasa digunakan untuk menyebut status para seniman sesuai dengan silsilah keturunannya, yaitu seniman turunan dan katurunan. Seniman turunan ialah para seniman yang dilahirkan dari keluarga seniman, dalam arti bapak dan ibunya adalah seniman. Sementara itu, seniman katurunan ialah para seniman yang dilahirkan dari keluarga seniman, namun hanya salah seorang saja yang menjadi seniman, yakni bapaknya atau ibunya saja (Suanda, 1991: 35).

Berkaitan dengan sistem pewarisan, CavalliSforza dan Feldman (dalam Berry et al, 1999: 32) mengemukakan terdapat dua jenis sistem pewarisan yakni "Vertical Transmission" dan "Horizontal Transmission". "Vertical Transmission" (Pewarisan Tegak) ialah sistem pewarisan yang berlangsung melalui mekanisme genetik yang diturunkan dari waktu ke waktu secara lintas generasi yakni melibatkan penurunan ciriciri budaya dari orang tua kepada anak-cucu. Dalam pewarisan tegak, orang tua mewariskan nilai, keterampilan, keyakinan, motif budaya, dan sebagainya kepada anak-cucu mereka. Oleh karena itu pewarisan tegak disebut juga "Biological

1 Alamat korespondensi: Jurusan Tari STSI Bandung. Jalan Buahbatu No. 212 Bandung. Email: n.rochmat@yahoo.com. 
Transmission" yakni sistem pewarisan yang bersifat biologis. "Horizontal Transmission" (Pewarisan Miring) ialah sistem pewarisan yang berlangsung melalui lembaga-lembaga pendidikan seperti sekolah-sekolah atau sanggar-sanggar. "Horizontal Transmission" terjadi ketika seseorang belajar dari orang dewasa atau lembaga-lembaga (misalnya dalam pendidikan formal) tanpa memandang apakah hal itu terjadi dalam budaya sendiri atau dari budaya lain.

Rasinah mendapatkan pengetahuan dan keterampilan menari topeng dari bapaknya melalui proses belajar dari panggung ke panggung yakni dengan mengikuti pertunjukan-pertunjukan yang dilakukan oleh bapaknya. Aerli, pewaris Tari Topeng Gaya Dermayon, belajar menari topeng di bawah bimbingan neneknya, Rasinah. Oleh karena itu, sistem pewarisan yang terjadi pada Tari Topeng Gaya Dermayon berlangsung melalui mekanisme genetik, yakni pewarisan dari orang tua kepada anak-cucu. Dengan demikian dapat dikatakan bahwa proses pewarisan Tari Topeng Gaya Dermayon dilakukan melalui sistem "Vertical Transmission".

Konsep mengenai sistem "Vertical Transmission" sebenarnya telah lama ada dalam budaya masyarakat Sunda, seperti dinyatakan dalam peribahasa: "Teng manuk teng, anak merak kukuncungan", yang artinya bahwa sifat/ perilaku anak tidak akan jauh berbeda dari sifat/ perilaku orang tuanya. Peribahasa ini menjelaskan bahwa sifat/perilaku orang tua biasanya akan menurun kepada anaknya. Demikian juga yang terjadi dalam seni tradisional Tari Topeng Gaya Dermayon. Lastra (bapak Rasinah) adalah seorang seniman yang berprofesi sebagai Dalang Wayang dan Dalang Topeng. Jiwa seniman ini kemudian diturunkan kepada Rasinah yang menjadi seorang Dalang Topeng dengan keahlian yang luar biasa. Wacih, anak Rasinah, meskipun tidak menjadikan Dalang Topeng sebagai profesinya tetapi ia memiliki jiwa seniman yang cukup baik. Ia bisa menari dan memainkan beberapa alat musik gamelan. Ia juga seorang penyanyi (sinden) yang baik. Aerli, cucu Rasinah, dengan potensi jiwa seniman yang dimilikinya memilih Dalang Topeng sebagai profesinya sehingga menjadi pewaris Tari Topeng Gaya Indramayu.

Menurut pengakuan Aerli, para leluhurnya adalah seniman yang berprofesi sebagai Dalang
Wayang atau Dalang Topeng pada zamannya masing-masing. Ia bahkan mengaku sampai saat ini memiliki sebuah topeng (Kedok Klana) yang telah berusia ratusan tahun sebagai salah satu warisan keluarga yang sangat berharga (Wawancara dengan Aerli, 24 November 2010). Penelitian ini bertujuan untuk memahami proses pewarisan Tari Topeng Darmayon.

\section{Proses Pewarisan}

Dalam kesenian tradisional Tari Topeng, yang dimaksud dengan proses pewarisan ialah proses pengalihan pengetahuan dan keterampilan menari topeng dari generasi tua kepada generasi muda dalam lingkungan keluarga Dalang Topeng. Proses pewarisan atau pengalihan pengetahuan ini erat hubungannya dengan praktik adat istiadat dalam konteks sebuah desa dan sesuai dengan lingkungan, adat, serta kepercayaan setempat. Proses pengalihan pengetahuan ini biasanya tidak dilakukan melalui pembelajaran yang spesifik, melainkan melalui pengalaman sehari-hari, pengamatan, dongeng-dongeng nenek moyang, dan sebagainya. Beberapa seniman Topeng Cirebon yang mengalami proses pembelajaran seperti itu antara lain Dasih, Sudji, Andet Suanda, Sudjana, Carpan, Rasinah, Dewi, dan Sawitri (Masunah, 2000: 5).

Proses pengalihan pengetahuan dan keterampilan menari topeng dari orang tua (Dalang Topeng) kepada keturunannya biasanya dilakukan secara lisan (oral tradition). Oleh karena itu, si anak harus mampu menyerap dan menghapal setiap gerakan yang diajarkan oleh orang tuanya melalui proses belajar yang berlangsung terus-menerus dengan mengikuti berbagai pertunjukan topeng yang dilakukan oleh orang tuanya. Jadi si anak belajar dengan cara melihat, mendengar, menirukan dan mengembangkan sendiri gerakan-gerakan Tari Topeng melalui pertunjukan orang tuanya dalam berbagai panggungan atau dikenal dengan istilah "Guru Panggung". Hal yang diandalkan dalam "Guru Panggung" itu adalah aspek melihat dan mendengar. Oleh sebab itu, berguru di panggung itu bukan hanya mempelajari tariannya saja, melainkan juga mempelajari bunyi-bunyi (tabuhan) iringan gamelannya (Rasidin, 2004: 34).

Seni rakyat diwariskan secara lisan dari generasi ke generasi. Seni rakyat adalah seni lokal sehingga berbeda lokalitasnya, akan berbeda 
seninya. Dalam budaya rakyat, tidak dikenal sistem pengawetan berupa pendokumentasian. Dokumentasi seni rakyat ada di masyarakat hanya dalam masa tertentu. Akibatnya, seni rakyat lebih "hidup", penuh improvisasi dan tafsir setempat, tidak ada pembakuan seni. Setiap lokal dapat mengembangkan sendiri tafsirnya atas warisan seni generasi sebelumnya (Sumardjo, 2002: 239).

Seni pertunjukan diajarkan atau diwariskan secara lisan oleh guru kepada muridnya (biasanya dari bapak kepada anaknya) dengan langsung melihat, mendengar, meniru, dan melakukannya. Jadi tidak ada patokan baku yang harus dipegang, semuanya berdasarkan penafsiran, baik pada guru maupun bagi si murid, sehingga penambahan, pengurangan, pengubahan bisa terjadi hanya dalam satu atau dua generasi. Inilah sebabnya varian suatu jenis tarian dapat cepat berkembang antara satu daerah dengan daerah lain, antara satu kurun waktu dengan waktu-waktu berikutnya (Sumardjo, 2001: 11).

Senada dengan hal tersebut, Sal Murgiyanto menyatakan:

Sebuah gaya tari tidaklah tetap sama bentuknya sepanjang zaman. Ia berubah ketika diajarkan oleh generasi tua kepada generasi muda karena bentuk tari yang diwariskan itu harus diinterpretasikan.......... Sesuatu yang diwariskan tidak berarti harus diterima, dihargai, diasimilasi, atau disimpan sampai mati. Bagi para pewaris yang setia, apa-apa yang mereka warisi tidak dilihat sebagai "tradisi". Tradisi yang diterima akan menjadi unsur yang hidup di dalam kehidupan para pendukungnya. Ia menjadi bagian dari masa lalu yang dipertahankan sampai sekarang dan mempunyai kedudukan yang sama dengan inovasi-inovasi baru (Murgiyanto, 2004: 2).

Seringkali hasil dari pewarisan bukan merupakan pengulangan atau tidak sama persis dengan generasi yang mewariskannya. Kasus ini hampir terdapat dalam banyak seni tradisi di Jawa Barat. Meskipun para Dalang Topeng Cirebon masih merupakan satu keturunan, namun mereka mempunyai gaya menari sendiri-sendiri. Setiap Dalang Topeng mempunyai ciri khas, estetis, serta kemampuan masing-masing di dalam menafsirkan tarian-tariannya (Caturwati, 2009:
143). Pengertian "kebaruan" dalam konteks tradisi sudah barang tentu bukan berarti menanggalkan gerak pokoknya begitu saja, tetapi menambah variasi gerak yang masih tetap berpegang pada akar ketradisiannya (Rasidin, 2004: 123).

Pada saat belajar menari topeng, Rasinah seringkali menyisipkan gerakan-gerakan yang ia tiru dari Dalang Topeng lain yang ia tonton. Rombongan topeng yang sering ditontonnya ialah rombongan Topeng Warimah dan rombongan Topeng Sureh yang cukup terkenal pada masa itu. Ketika bapaknya mengetahui Rasinah menyisipkan gerakan-gerakan hasil peniruannya, ia sangat terkejut tetapi akhirnya menerima dan mempersilahkan apa-apa yang telah dilakukan oleh Rasinah selama gerak-gerak tariannya terlihat bagus (Rasidin, 2004: 46).

Dalam upaya mempertahankan dan melestarikan kesenian tradisional Tari Topeng, para Dalang Topeng senantiasa berusaha untuk mewariskan pengetahuan dan keterampilan mereka kepada anak-cucu mereka. Lastra telah mewariskan pengetahuan dan keterampilan menari topeng kepada anaknya (Rasinah). Demikian halnya dengan Rasinah telah mewariskan pengetahuan dan keterampilan menari topeng kepada anak dan cucunya. Ditinjau dari pelaksanaannya, proses pewarisan dalam Tari Topeng Gaya Dermayon berlangsung dalam dua cara yakni: 1) pewarisan tidak resmi, dan 2) pewarisan resmi.

\section{Pewarisan Tidak resmi}

Proses pewarisan tidak resmi biasanya sudah dilakukan oleh orang tua (Dalang Topeng) kepada keturunannya sejak si anak masih kecil. Sebagai contoh, Rasinah sudah belajar menari topeng ketika ia berusia sekitar 7 tahun. Sejak saat itulah proses pewarisan Tari Topeng secara tidak resmi dari bapak kepada anak dimulai. Aerli sudah belajar menari topeng di bawah bimbingan neneknya ketika ia duduk di bangku kelas 4 SD (sekitar tahun 1997). Sejak saat itu Rasinah memberikan amanat kepada Aerli untuk menjadi penerusnya, dan proses pewarisan secara tidak resmi pun dimulai.

Proses pewarisan tidak resmi kadang juga sudah dilakukan sejak si anak masih bayi, bahkan ketika anak masih di dalam kandungan ibunya. Ketika Sarminah, ibu kandung Rasinah, sedang mengandung ia seringkali ikut suaminya 
mengadakan pertunjukan dari panggung ke panggung. Dengan demikian sebelum lahir ke dunia sang bayi di dalam janin sudah terbiasa mendengarkan riuhnya alunan gamelan yang dimainkan oleh rombongan bapaknya. Demikian pula setelah Rasinah dilahirkan ke muka bumi, bayi kecil ini sudah terbiasa dibawa pentas dari satu panggung ke panggung lainnya. Terkadang si bayi kecil Rasinah ditidurkan beralaskan kain di tempat pagelaran. Lastra dan Sarminah tampaknya tidak perduli bayinya kepanasan, kegaduhan suara orang atau pun keramaian suara gamelan. Si bayi kecil Rasinah seakan "dininabobokan" oleh aura topeng (Rasidin, 2004: 35).

Dalam proses belajar menari topeng, si anak tidak secara langsung diajarkan tentang teknik tariannya, ia hanya disuruh melihat dan memperhatikan gerakan-gerakan yang dibawakan oleh orang tuanya ketika sedang menari di atas panggung. Kemudian ia menirukan gerakangerakan orang tuanya di belakang panggung. Proses belajar seperti ini dilakukannya selama bertahuntahun sampai akhirnya ia disuruh langsung menari oleh orang tuanya ketika sedang melakukan pertunjukan bebarang atau pertunjukan hajatan. Pada kesempatan itulah orang tua menunjukkan dan membetulkan gerakan-gerakan yang dianggap belum sesuai dengan ketentuan-ketentuan yang dianutnya. Proses belajar seperti ini berlangsung sangat lama karena hanya mengandalkan waktuwaktu senggang saja, biasanya dilakukan pada sore atau malam hari atau pada saat orang tuanya tidak ada panggungan (Suanda, 1989: 58).

Dalam seni tradisi, proses transformasi biasanya berjalan secara alami. Nyaris tidak ada tanyajawab antara yang mewariskan (pemberi) dan yang diwarisi (penerima). Prinsipnya adalah lakukan saja, mainkan saja, nanti pun bisa atau tahu sendiri. Prinsip ini dianut di kalangan seniman tradisi yang seringkali membiarkan penerima untuk bisa dan mengetahuinya sendiri (Suanda, 2009: 21).

Proses pengalihan pengetahuan dan keterampilan seni pertunjukan tradisional dari orang tua kepada anaknya, dikemukakan juga oleh James R. Brandon sebagai berikut:

The forms and formulas of Southeast Asian Theatre are preserved and transmitted to succeeding generations through traditional teaching methods conspicuously different from those

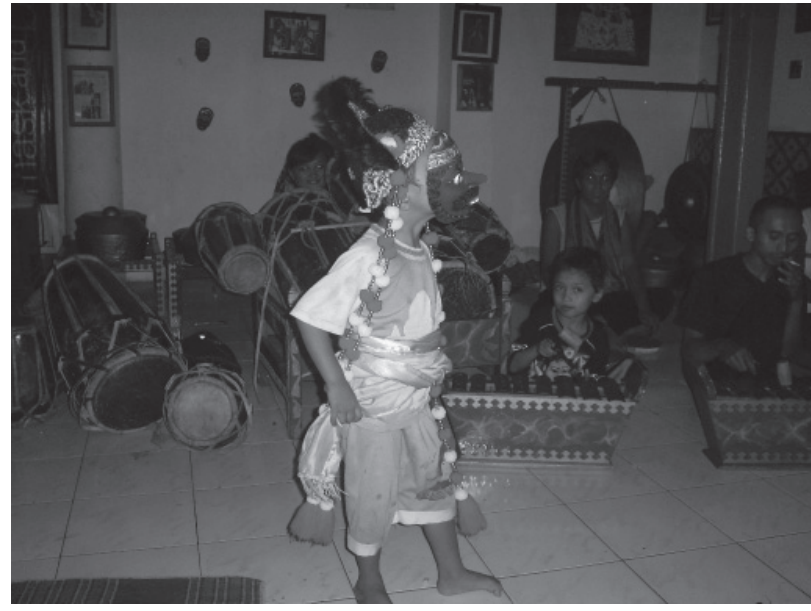

Gambar 1. Anak laki-laki Aerli sedang berlatih menari Topeng di sanggarnya. (Foto: Nur Rochmat, 2010)

used in the West. The simplest of these is perhaps the most common: a youngster sits backstage; he watches and listens to performances; he learns. As time goes by this young apprentice is given minor tasks. He becomes a spear-carrier or plays one of the easier instruments... The learning situation is unstructured and informal (Brandon, 1967: 155).

Untuk menguasai keterampilan menari topeng tidak bisa dilakukan dalam waktu singkat. Menurut Wacih, proses belajar menari topeng memerlukan waktu yang sangat lama sehingga ia dulu tidak mau berlatih menari topeng. Dari kecil ia hanya mau berlatih tari-tari kreasi yang diciptakan oleh ibunya karena dianggap lebih sederhana dan lebih cepat mempelajarinya. Ia mulai berlatih menari topeng setelah ia dewasa dan mempunyai anak (Wawancara dengan Wacih, 24 November 2010).

Sementara itu Aerli mengatakan bahwa ia mulai berlatih menari topeng dari neneknya sejak ia berusia sekitar 10 tahun. Proses belajar menari topeng yang sangat lama ini juga diakui oleh Aerli. Ia bahkan harus mempelajari satu jenis tarian topeng selama tiga tahun sebelum diperbolehkan pentas oleh neneknya (Wawancara dengan Aerli, 24 November 2010).

Hal senada juga dikemukakan oleh Juju Masunah:

Berbeda dari bentuk seni pertunjukan rakyat yang lain, gaya daerah dan gaya individu Topeng Cirebon memiliki perbendaharaan gerak yang tidak sederhana sehingga tarian 
Topeng Cirebon tidak bisa ditiru atau dipelajari hanya dengan satu atau dua kali melihat saja. Untuk menguasai tarian tersebut diperlukan motivasi tinggi dan waktu yang lama untuk belajar melalui proses pewarisan (Masunah, 2003: 227).

Setelah menjalani proses belajar menari topeng selama bertahun-tahun di bawah asuhan Rasinah, Aerli saat ini sudah menguasai semua gerakan Tari Topeng yang telah diajarkan oleh neneknya tersebut. Hal ini pun diakui oleh Wacih bahwa kemampuan Aerli dalam menari topeng jauh melebihi kemampuannya yang hanya berlatih menari topeng setelah ia berusia dewasa. Ia mengakui bahwa proses belajar menari topeng yang ia lakukan tidaklah terlalu lama (Wawancara dengan Wacih, 24 Novemebr 2010).

Lamanya waktu yang dibutuhkan untuk mempelajari dan menguasai Tari Topeng juga dialami oleh Wardiningsih, salah satu bekas murid Rasinah. Ia menuturkan bahwa dulu sekitar tahun 1960-an ketika ia belajar menari topeng kepada Rasinah sangatlah sulit untuk menguasai gerakangerakan yang ada dalam Tari Topeng. Ia bahkan memerlukan waktu berbulan-bulan hanya untuk menguasai salah satu gerakan dalam tarian ini (Wawancara dengan Wardiningsih, 24 November 2010).

Selain harus menjalani proses belajar yang cukup lama, seorang Penari Topeng juga harus menjalani berbagai laku spiritual yang cukup berat agar dapat menjadi Dalang Topeng yang memiliki kemampuan menari yang sangat baik serta agar dapat "menyatu" dengan jiwa topeng yang dikenakannya dan dipercaya memiliki kekuatan magis. Oleh karena itu, tidaklah mengherankan apabila seorang Dalang Topeng sedang menari, seolah-olah ada roh lain yang merasuk ke dalam jiwanya sehingga ia mampu menari selama berjamjam dengan kekuatan fisik yang luar biasa tanpa terlihat kelelahan. Wacih mengatakan bahwa ketika Rasinah sudah memakai topeng untuk menari, seolah-olah yang sedang menari itu bukan Rasinah tetapi yang tampak adalah seorang tokoh dari karakter topeng yang sedang ditarikannya. Ketika Rasinah sedang menari dan memerankan Topeng Klana, maka yang tampak di hadapan penonton adalah seorang tokoh Klana yang benarbenar gagah perkasa, bukan lagi seorang nenek tua yang kurus kering tak berdaya.

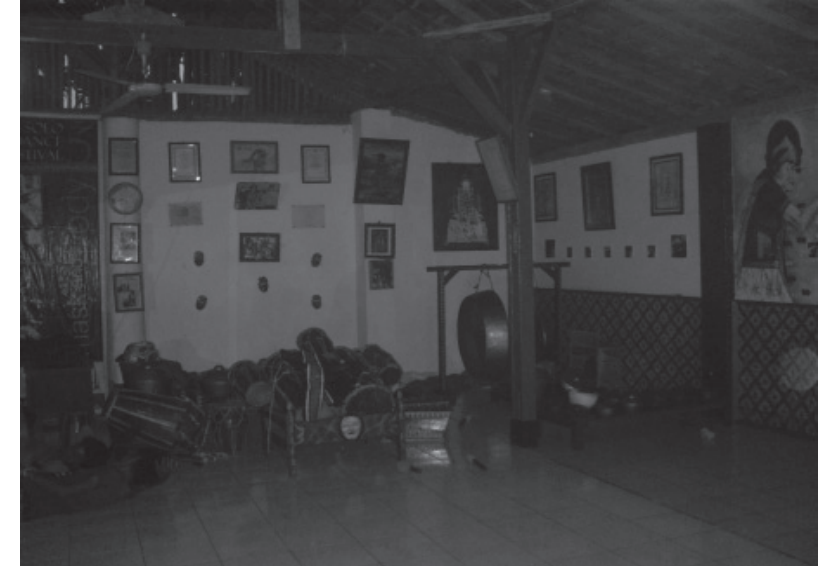

Gambar 2. Sanggar Tari Topeng Rasinah, Pekandangan, Indramayu. (Foto: Nur Rochmat, 2010)

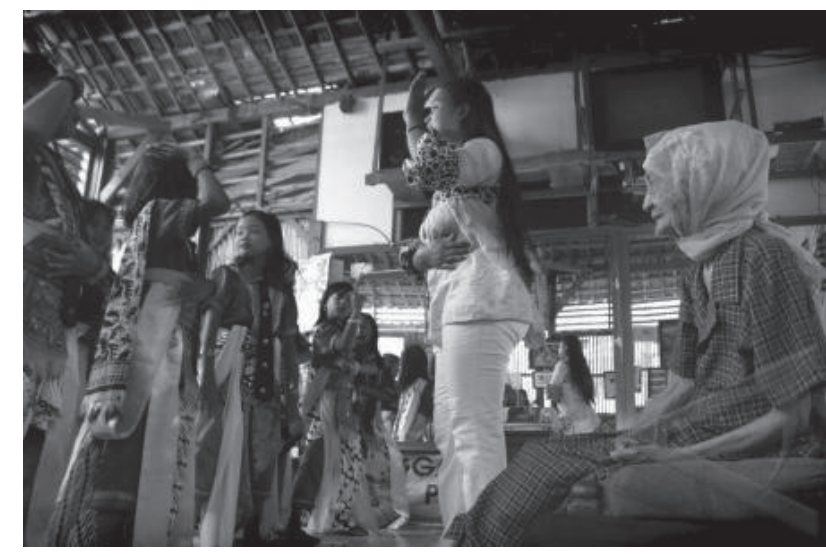

Gambar 3. Rasinah mengawasi Aerli yang sedang melatih tari kepada anak-anak yang belajar menari topeng di sanggarnya. (Foto: Sri Hastuti, 2010)

Pada umumnya para Dalang Topeng Cirebon mempunyai latar belakang yang sama dalam mencapai tingkat kepenariannya. Sebelum seseorang menjadi Dalang Topeng, terlebih dahulu ia harus menempuh suatu sistem penempaan diri di bidang kepenarian melalui proses alami yang begitu panjang. Proses tersebut bukan hanya mengenai teknik tari dan menari tetapi juga proses penempaan yang bersifat kejiwaan/batiniah. Seseorang yang akan menjadi Dalang Topeng harus menempuh jalan penyucian diri (laku spiritual) melalui berbagai cara tradisi. Proses penempaan diri yang bersifat kejiwaan ini ditempuh secara bertahap yang disebut dengan "meuseuh diri". Kegiatan meuseuh diri dilakukan dengan berbagai cara, di antaranya: puasa, tapa/semedi, mutih (hanya makan nasi saja tanpa dibarengi lauk-pauk), tidur hanya boleh beralaskan tikar, dan lain-lain. Cara-cara meuseuh 
diri tersebut dimaksudkan untuk menumbuhkan keyakinan diri dan untuk memperoleh kekuatan tambahan serta dimaksudkan agar Dalang Topeng tersebut menjadi laris di masyarakat (Suanda, 1989: 55).

Hal senada juga diungkapkan oleh Tati Narawati:

Agar memiliki kekuatan dan keutamaan, seorang Dalang Topeng dituntut untuk melakukan tirakat sepanjang hayat. Melatih fisik secara spiritual untuk mendapatkan daya magis lewat tata laku. Dia harus menahan dan melawan keinginan serta nafsu alamiahnya untuk pencapaian tujuan yang positif lewat kekuatan-kekuatan yang sangat dipertinggi. Untuk itu dia rela makan dan minum dengan menu menurut pola kepercayaan tradisi (Narawati, 2005: 102).

Dalam upayanya untuk mensucikan diri, Rasinah melakukan berbagai jenis puasa, di antaranya: ngetan (tidak makan nasi kecuali hanya makan secangkir nasi ketan setiap hari selama 40 hari), puasa pisang (hanya makan dua buah pisang sehari selama 7 hari), nguler (hanya makan daun-daunan seperti bayam dan kangkung selama 7 atau 21 hari), balakandem (hanya makan jenis umbi-umbian seperti singkong, kentang dan ubi selama 40 hari), rawit (hanya makan beberapa cabe rawit setiap hari selama 1 minggu), dan lainlain (Rasidin, 2004: 57).

Proses penempaan diri adalah pendidikan/ latihan jiwa yang harus dijalankan oleh setiap Dalang Topeng karena merupakan salah satu dari serangkaian proses pewarisan yang diturunkan dari Dalang Topeng kepada anak-cucu mereka. Menurut pengakuan Carpan, dalang Topeng asal Ciberang Indramayu, hingga saat ini ia masih melaksanakan beberapa laku spiritual untuk menjaga kesehatan dan ketahanan fisiknya, di antaranya dengan berpuasa selama tujuh hari dalam setiap bulan (Wawancara dengan Carpan, 25 November 2010). Aerli pun mengaku bahwa ia sudah melaksanakan berbagai laku spiritual seperti yang telah diajarkan/dilakukan oleh Rasinah. Akan tetapi dari sekian jenis puasa yang harus dilakukan, ia mengaku tidak kuat melaksanakan "rawit" (hanya makan beberapa cabe rawit setiap hari selama 1 minggu). Ia hanya kuat melaksanakannya selama 3 hari (Wawancara dengan Aerli, 24 November 2010).

\section{Pewarisan Resmi}

Proses pewarisan secara resmi dilakukan oleh orang tua (Dalang Topeng) kepada anak (keturunannya) ketika orang tua merasa bahwa anaknya tersebut sudah menguasai semua gerakan (pokok) dalam Tari Topeng dan sudah dianggap pantas dinobatkan sebagai "ahli warisnya". Proses pewarisan ini dilaksanakan secara resmi dan melalui ritual tertentu yang harus dipenuhi oleh calon ahli warisnya tersebut. Dalam pelaksanaannya, orang tua (pewaris) memberikan seluruh perlengkapan topeng dan aksesorisnya kepada anaknya untuk dapat menjaga, mempertahankan dan melestarikan Tari Topeng sebagai warisan budaya leluhur mereka.

Tari Topeng biasanya diwariskan dari generasi ke generasi di dalam lingkungan keluarga Dalang Topeng itu sendiri. Salah satu contohnya ialah Keni (Dalang Topeng dari Slangit, Cirebon). Keni belajar menari topeng di bawah bimbingan bapaknya, Arja, dan kakak kandungnya, Sujana. Kemudian Kenimenurunkankembalipengetahuan dan keterampilan menari topeng tersebut kepada anaknya, Nunung Nurasih. Berbeda dari Tari Topeng gaya lainnya, pada Tari Topeng Gaya Rasinah terdapat satu loncatan generasi pewarisan yakni dari Rasinah tidak diwariskan kepada anaknya tetapi langsung diwariskan kepada cucunya. Beberapa alasan yang melatarbelakangi loncatan generasi pewarisan tersebut di antaranya sebagai berikut.

Pada waktu Wacih masih kecil, sekitar tahun 1970an-1980an, keadaan ekonomi keluarga Rasinah sangat memprihatinkan, sedangkan pertunjukan Tari Topeng yang menjadi mata pencaharian Rasinah sudah sangat jarang mendapat undangan pentas dari masyarakat, sehingga rombongan Topeng Rasinah mengalami masa kevakuman. Oleh karena itu Wacih tidak memiliki motivasi untuk mempelajari ataupun menjadikan Tari Topeng sebagai profesi/sandaran hidupnya (Wawancara dengan Wacih, 24 November 2010).

Di lain pihak, Aerli mulai mempelajari Tari Topeng pada tahun 1990an ketika Tari Topeng Gaya Dermayon sudah mulai terkenal di dunia internasional, dan Rasinah sudah mengalami pentas di berbagai kota besar di dalam negeri dan luar negeri. Selain itu, kehidupan ekonomi keluarga Rasinah pun mulai mengalami peningkatan karena banyaknya undangan pertunjukan. 
Rumah keluarga Rasinah yang hampir roboh pun dibangun kembali dan diikuti dengan pembangunan sanggar tarinya. Pembangunan rumah dan sanggar tari ini dilakukan atas usaha besar para seniman, terutama Endo Suanda, Toto Amsar Suanda, dan lain-lain. Menyaksikan keberhasilan yang telah diraih oleh Rasinah dan besarnya atensi dari berbagai pihak, khususnya para seniman terhadap Tari Topeng menimbulkan adanya motivasi dan semangat dalam diri Aerli untuk belajar menari topeng dengan sungguhsungguh dan menjadikan Dalang Topeng sebagai profesinya (Wawancara dengan Aerli, 24 November 2010).

Berkaitan dengan motivasi, Robert Session Woodworthdan ClarkHull (dalamKoeswara, 1995: 67-68) mengungkapkan bahwa seluruh tingkah laku (kecuali refleks-refleks) itu bermotivasi. Tanpa adanya dorongan, tidak akan ada kekuatan yang menggerakkan dan mengarahkan mekanismemekanisme yang bertindak sebagai pemuncul tingkah laku. Pendek kata, dorongan itu perlu bagi kemunculan tingkah laku. Dorongan itu sendiri diaktifkan oleh kebutuhan yang timbul akibat keadaan kekurangan pada tubuh atau kekurangan fisiologis, yang pada gilirannya dorongan mengaktifkan tingkah laku organisme.

Sementara itu Abraham H. Maslow mengungkapkan:

Kebutuhan yang biasanya dijadikan titik tolak teori motivasi adalah apa yang disebut dengan dorongan fisiologis (rasa lapar, mengantuk, hasrat seksual, dan lainlain).... Kebutuhan fisiologis manapun dan kebutuhan konsumtif yang sejalan dengan itu berfungsi sebagai penyalur segala macam kebutuhan lainnya. Kebutuhan fisiologis ini adalah kebutuhan yang paling kuat. Tegasnya bahwa pada diri manusia yang selalu merasa kurang dalam kehidupannya, kebutuhan fisiologislah yang merupakan motivasi terbesar dan bukan kebutuhan yang lain (Maslow, 1994: 44-45).

Ketika kebutuhan utama (fisiologis) tidak terpenuhi, maka seseorang tidak akan terdorong untuk melakukan hal lain bahkan akan melupakan kebutuhan yang lain. Pada tahun 1970an kegiatan kesenian Tari Topeng mengalami kemunduran sehingga tidak dapat dijadikan tumpuan untuk mencari nafkah. Demikian juga yang terjadi pada
Rasinah. Rombongan topengnya sudah tidak dapat menopang kebutuhan hidup keluarganya. Rasinah tidak bisa meminta anaknya untuk menjadi Dalang Topeng seperti dirinya karena pada saat itu ia pun menyadari bahwa menjadi Dalang Topeng tidak bisa menjamin kehidupan ekonominya. Demikian juga dengan Wacih, satu-satunya anak Rasinah yang masih hidup, tidak tertarik untuk menjadi Dalang Topeng karena ia menganggap menjadi Dalang Topeng tidak mempunyai masa depan ekonomi yang jelas. Ia hanya berpikir bagaimana caranya untuk memenuhi kebutuhan hidup yang serba sulit pada masa itu sehingga ia tidak mempunyai motivasi atau dorongan untuk belajar Topeng secara lebih serius.

Dari hal-hal yang dikemukakan di atas dapat dikatakan bahwa pewarisan Tari Topeng Gaya Dermayon dari nenek kepada cucunya dan bukan kepada anaknya dikarenakan beberapa faktor, di antaranya (1) Tidak adanya motivasi dalam diri Wacih untuk menjadi seorang Dalang Topeng sehingga sejak kecil ia tidak mau mempelajari Tari Topeng, artinya ia tidak mengalami proses pewarisan secara tidak resmi. Sementara itu, Aerli memiliki motivasi yang tinggi untuk menjadi seorang Dalang Topeng sehingga sejak kecil ia sudah mempelajari Tari Topeng dengan sungguhsungguh, artinya ia mengalami proses pewarisan tidak resmi di bawah bimbingan neneknya. (2) Lamanya proses belajar menari topeng yang dilakukan oleh Aerli membuat ia memiliki keahlian menari topeng yang jauh lebih baik daripada ibunya sehingga Aerli dianggap lebih pantas untuk menjadi pewaris Tari Topeng dari Rasinah.

Pada tanggal 15 Maret 2008 Rasinah secara resmi memberikan amanat kepada Aerli melalui kegiatan ritual untuk meneruskan tradisi Tari Topeng Gaya Dermayon. Dalam pelaksanaan ritual tersebut Aerli harus melakukan pertunjukan bebarang di tujuh tempat yang berbeda. Tepat pada pukul 08.00 pagi mulailah Aerli bersama rombongan topengnya berkeliling dari kampung ke kampung melakukan pertunjukan bebarang sebagai salah satu syarat yang harus dipenuhinya untuk dapat mewarisi kesenian tradisional Tari Topeng dari sang nenek. Pertunjukan bebarang tersebut berlangsung selama kurang lebih 8 jam yang berakhir pada sore hari. Lokasi terakhir yang dipilih untuk melakukan pertunjukan bebarang 
adalah di pinggir Sungai Cimanuk. Tempat itu dipilih karena filosofinya bahwa "ilmu" Tari Topeng akan terus mengalir ke anak cucu seperti halnya air sungai yang terus mengalir. Aerli beserta rombongan topengnya pun kembali ke rumahnya tepat pada pukul 16.00. Setelah itu Aerli menerima warisan beberapa buah Topeng (Kedok), seperangkat baju dan aksesoris yang biasa dikenakan oleh Rasinah untuk menari topeng. Sejak saat itu Aerli secara resmi menjadi pewaris Tari Topeng Gaya Dermayon dari Rasinah.

\section{Penutup}

Tari Topeng Gaya Dermayon telah mampu mempertahankan eksistensinya melalui pewarisan yang dilakukan secara turun temurun. Bagi para Dalang Topeng, tugas untuk menjaga dan mempertahankan kesenian tradisional Tari Topeng bukanlah merupakan sebuah beban tetapi menjadi kewajiban mulia untuk melestarikan budaya sebagai warisan dari leluhurnya.

Proses pewarisan kesenian tradisional Tari Topeng Gaya Dermayon berlangsung melalui sistem "Pewarisan Tegak" atau melalui mekanisme genetik, yakni sistem pewarisan budaya dari orang tua kepada anak-cucu. Salah satu alasan yang melatarbelakangi loncatan generasi pewarisan pada Tari Topeng Gaya Dermayon ialah faktor motivasi dalam diri seniman pelakunya.

\section{Kepustakaan}

Berry, John W. et al. 1999. Psikologi Lintas Budaya, Riset dan Aplikasi. Terjemahan Edi Suhardono. Jakarta: Gramedia Pustaka Utama.

Brandon, James R. 1967. Theatre in Southeast Asia. Cambridge, Massachusetts: Harvard University Press.

Caturwati, Endang. 2009. Rekonstruksi dan Revitalisasi Seni Topeng Cirebon dalam Pemaknaan Kehidupan Masyarakat Mandiri, Dinamis dan Sejahtera. Laporan Penelitian Prioritas Nasional. Jakarta: Departemen Pendidikan Nasional. Direktorat Jenderal Pendidikan Tinggi.

Koeswara, E. 1995. Motivasi: Teori dan Penelitiannya. Bandung: Angkasa.
Maslow, Abraham H. 1994. Motivasi dan Kepribadian 1: Teori Motivasi dengan Pendekatan Hierarki Kebutuhan Manusia. Terjemahan Nurul Imam. Bandung: Remaja Rosdakarya Offset.

Masunah, Juju. 2000. Sawitri Penari Topeng Losari. Bandung: Tarawang.

dan Tati Narawati. 2003. Seni dan Pendidikan Seni. Sebuah Bunga Rampai. Bandung: P4ST UPI.

Murgiyanto, Sal. 2004. Tradisi dan Inovasi: Beberapa Masalah Tari di Indonesia. Jakarta: Wedatama Widya Sastra.

Narawati, Tati. dan Soedarsono, R.M. 2005. Tari Sunda. Dulu, Kini, dan Esok. Bandung: P4ST UPI.

Rasidin, Dindin. 2004. Rasinah Dalang Topeng Indramayu Jawa Barat. Sebuah Biografi. Tesis. Yogyakarta: Program Pascasarjana Universitas Gadjah Mada.

Suanda, Endo. 1991. "Seniman Cirebon dalam Konteks Sosialnya”. Buletin Seni Pertunjukan Indonesia. Surakarta: MSPI.

Suanda, Toto Amsar. 1989. Tari Topeng Panji sebagai Tari Meditasi. Bandung: Akademi Seni Tari Indonesia. 2009. Tari Topeng Panji Cirebon. Suatu Kajian Simbolis. Tesis. Program Pascasarjana. Yogyakarta: Institut Seni Indonesia.

Sumardjo, Jakob, et al. 2001. Seni Pertunjukan Indonesia. Bandung: STSI Press.

. 2002. Arkeologi Budaya Indonesia; Pelacakan Hermeneutis-Historis terhadap Artefak-Artefak Kebudayaan Indonesia. Yogyakarta: Qalam.

\section{Informan}

Aerli (23 tahun). Ketua Sanggar Tari Topeng Rasinah (cucu Rasinah).

Carpan (70 tahun). Dalang Topeng dari desa Cibereng, Indramayu.

Wacih (40 tahun). Putri Rasinah.

Wardiningsih (54 tahun). Kepala Sekolah SDN Kepandean I. Salah seorang murid Rasinah. 